\title{
Gardenia jasminoides Extract Attenuates the UVB-Induced Expressions of Cytokines in Keratinocytes and Indirectly Inhibits Matrix Metalloproteinase-1 Expression in Human Dermal Fibroblasts
}

\author{
Jiaa Park, ${ }^{1}$ Jin Kyung Seok, ${ }^{1}$ Hwa-Jin Suh, ${ }^{2}$ and Yong Chool Boo ${ }^{1,3}$ \\ ${ }^{1}$ Department of Molecular Medicine, Cell and Matrix Research Institute, BK21 Plus KNU Biomedical Convergence Program, \\ Kyungpook National University School of Medicine, Daegu 700-422, Republic of Korea \\ ${ }^{2}$ Gyeongbuk Natural Color Industry Institute, Gyeongbuk, Republic of Korea \\ ${ }^{3}$ Ruby Crown Co., Ltd., Daegu, Republic of Korea \\ Correspondence should be addressed to Yong Chool Boo; ycboo@knu.ac.kr
}

Received 4 November 2013; Revised 28 January 2014; Accepted 3 February 2014; Published 11 March 2014

Academic Editor: Ki-Wan Oh

Copyright (C) 2014 Jiaa Park et al. This is an open access article distributed under the Creative Commons Attribution License, which permits unrestricted use, distribution, and reproduction in any medium, provided the original work is properly cited.

\begin{abstract}
Ultraviolet radiation (UV) is a major cause of photoaging, which also involves inflammatory cytokines and matrix metalloproteinases (MMP). The present study was undertaken to examine the UVB-protecting effects of yellow-colored plant extracts in cell-based assays. HaCaT keratinocytes were exposed to UVB in the absence or presence of plant extracts, and resulting changes in cell viability and inflammatory cytokine expression were measured. Of the plant extracts tested, Gardenia jasminoides extract showed the lowest cytotoxicity and dose-dependently enhanced the viabilities of UVB-exposed cells. Gardenia jasminoides extract also attenuated the mRNA expressions of interleukin-1 $\beta$ (IL-1 $\beta$ ) and tumor necrosis factor- $\alpha$ (TNF- $\alpha$ ) in HaCaT cells stimulated by UVB. Conditioned medium from UVB-exposed HaCaT cells was observed to stimulate MMP-1 protein expression in human dermal fibroblasts, and this effect was much smaller for the conditioned medium of HaCaT cells exposed to UVB in the presence of Gardenia jasminoides extract. Gardenia jasminoides extract also exhibited antioxidative and antiapoptotic effects in HaCaT cells exposed to UVB. These results indicated that UVB-induced injury and inflammatory responses of skin cells can be attenuated by yellow-colored plant extracts, such as Gardenia jasminoides extract.
\end{abstract}

\section{Introduction}

Cosmetics have become essential products as people pursue esthetic desires in modern society, and their role has been extended to the retardation of skin aging caused by physiological and environmental factors. Ultraviolet radiation (UV) is a major cause of skin aging, which is characterized by wrinkles, laxity, blister formation, roughness, and loss of skin tone [1-3]. Therefore, there is considerable interest in the development of safer, more effective ingredients that mitigate the harmful effects of UV.

Photoaging involves changes in dermal extracellular matrix composition and collagen loss. Matrix metalloproteinases (MMPs), a group of zinc endopeptidases, play a key role in the turnover of extracellular matrix macromolecules, including type I collagen $[4,5]$. Furthermore, the expressions of MMPs, such as MMP-1, -2, -3 , and -9 , are known to be upregulated in UV-exposed human dermal fibroblasts $[6,7]$. These MMPs can regulate the remodeling of connective tissues associated with the formation of wrinkles and other phenotypes of photoaging. Thus, the pharmacological targeting of MMPs is considered a promising strategy to reduce the photoaging process [8].

The UVB-induced upregulation of MMPs is mainly mediated by signal transduction pathways involving the UVinduced activation of cytokine receptors and the subsequent activations of mitogen-activated protein kinases, such as extracellular signal-regulated kinase, c-Jun-N-terminal 


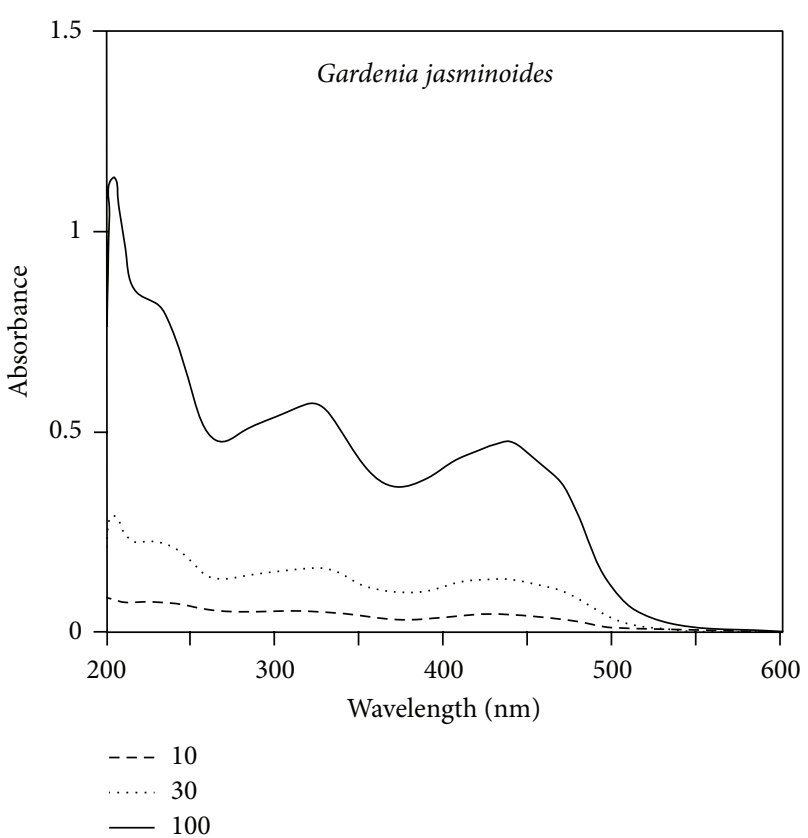

(a)

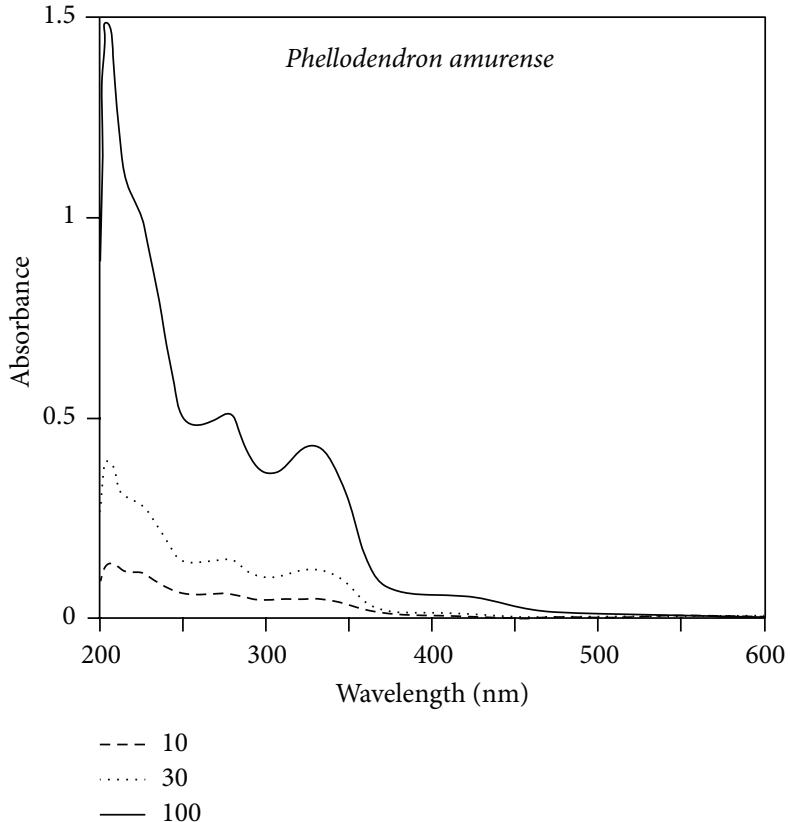

(b)

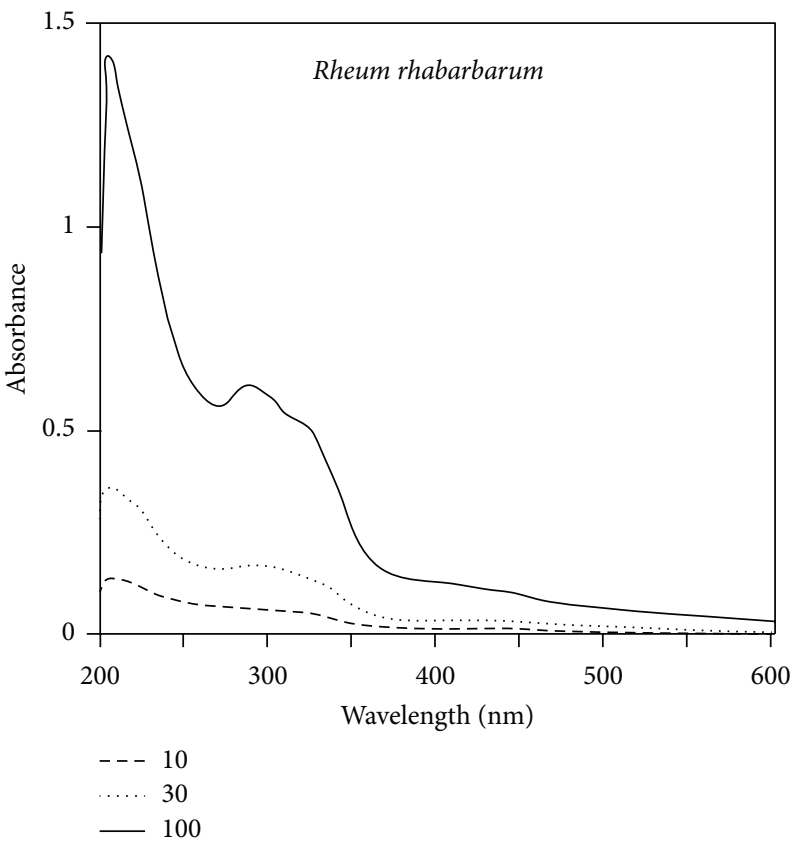

(c)

FIGURE 1: Absorption spectra of plant extracts. Extracts from Gardenia jasminoides (a), Phellodendron amurense (b), and Rheum rhabarbarum (c) were dissolved in PBS at concentrations of 10,30 , or $100 \mu \mathrm{g} \mathrm{mL}^{-1}$.

kinase, and p38 kinase, which in turn leads to the activations of transcription factors, such as activator protein-1 (AP-1) complexes [9-11]. In fact, the promoters of MMP-1 and MMP3 genes carry AP-1 sites that are transactivated by the binding of active AP-1 complexes, which results in the initiation of MMP gene transcription [10,12]. Although the initial events underlying this signal cascade are not fully understood, available evidence supports the notion that UV-damaged DNA acts as a primary signal [13].

The communication between epidermal keratinocytes and dermal fibroblasts is important in terms of skin response to various external stimuli, including UV. MMP-1 expression 


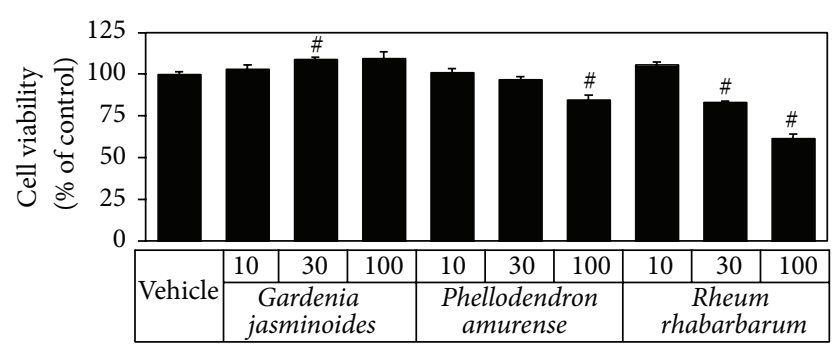

FIgURE 2: Effects of plant extracts derived from Gardenia jasminoides, Phellodendron amurense, and Rheum rhabarbarum on the viability of $\mathrm{HaCaT}$ keratinocytes. Cells were treated with plant extracts at the indicated concentration for $24 \mathrm{~h}$ and cell viabilities were determined using an MTT assay. Cell viabilities are presented as percentages of the vehicle control (means \pm SEs; $n=3$ ). ${ }^{\#} P<0.05$ versus the vehicle control.

in dermal fibroblasts can be stimulated by direct exposure of the fibroblasts to UV. In addition, MMP-1 expression in dermal fibroblasts can be stimulated indirectly by the cytokines or other factors secreted by epidermal keratinocytes exposed to UV. Previous studies have shown that the conditioned medium from UV irradiated keratinocytes effectively increases MMP-1 expression in fibroblasts via paracrine effects $[14,15]$. Thus, MMP-1 expression in dermal fibroblasts may be regulated indirectly by inhibiting the activation of epidermal keratinocytes in response to UV. In this regard, plant extracts with UV-shielding, antioxidative, and anti-inflammatory properties are an attractive prospect $[16,17]$.

The purpose of the present study was to examine the protective effects of plant extracts derived from Gardenia jasminoides, Phellodendron amurense, and Rheum rhabarbarum against skin cell responses to UV. These yellow plant extracts were chosen because of their ability to absorb UV effectively.

\section{Materials and Methods}

2.1. Plant Materials. Extracts of Gardenia jasminoides Ellis (seed), Phellodendron amurense Rupr. (root), and Rheum rhabarbarum L. (root) were prepared at Gyeongbuk Natural Color Industry Institute (http://www.gnc.re.kr/). Voucher specimens of the plants and other information regarding the extracts are available at this institute. Plant materials were extracted with hot water $80^{\circ} \mathrm{C}$ for $2 \mathrm{~h}$ and extracts were evaporated to dryness under reduced pressure.

2.2. UV Spectrophotometry. Test materials were dissolved in phosphate buffered saline (PBS) to final concentrations of 10,30 , and $100 \mu \mathrm{g} \mathrm{mL}^{-1}$. Absorption spectra were recorded in the 200 600 $\mathrm{nm}$ range using a Shimadzu UV-1650PC spectrophotometer (Shimadzu Corporation, Kyoto, Japan).

2.3. HPLC Analysis. HPLC analysis of extracts was done using a Gilson HPLC system (Gilson, Inc., Middleton, WI, USA) equipped with a 321 pump and UV/VIS 151 detector. Aqueous solution of test materials $\left(1.0 \mathrm{mg} \mathrm{mL}^{-1}\right)$ was injected at $10 \mu \mathrm{L}$. Separation was done on a $5 \mu \mathrm{m}$ Hector-M C18 column (4.6 mm $\times 250 \mathrm{~mm})$ (RS Tech Co., Daejeon, Korea). The mobile phase consisted of $0.5 \%$ formic acid (A) and acetonitrile (B). The gradient was programmed as follows: 0$20 \mathrm{~min}$, a linear gradient from 20 to $80 \% \mathrm{~B} ; 20-35 \mathrm{~min}, 80 \% \mathrm{~B}$. The flow rate was $0.5 \mathrm{~mL} \mathrm{~min}^{-1}$. The UV detector was set at $280 \mathrm{~nm}$ and $440 \mathrm{~nm}$. Purified crocin was purchased from Sigma-Aldrich (St. Louis, MO, USA) and its purity was determined spectrophotometrically using the extinction coefficient $\varepsilon_{443}=89,000 \mathrm{M}^{-1} \mathrm{~cm}^{-1}[18]$.

2.4. HaCaT Cell Culture. HaCaT cells (a human immortalized keratinocyte cell-line) were grown in DMEM/F-12 medium (GIBCO-BRL, Grand Island, NY, USA) supplemented with a $10 \%$ fetal bovine serum, $100 \mathrm{U} \mathrm{mL}^{-1}$ penicillin, $0.1 \mathrm{mg} \mathrm{mL}^{-1}$ streptomycin, $0.25 \mu \mathrm{g} \mathrm{mL}^{-1}$ amphotericin $\mathrm{B}$, and $10 \mu \mathrm{g} \mathrm{mL}^{-1}$ hydrocortisone. Cells were cultured at $37^{\circ} \mathrm{C}$ in a humidified atmosphere containing $5 \% \mathrm{CO}_{2}$ and $95 \%$ air.

2.5. UVB-Exposure of HaCaT Cells. HaCaT cells were seeded on a six-well plate at a density of $2 \times 10^{5}$ cells per well and grown in a culture medium for $48 \mathrm{~h}$ to reach $80 \%$ confluency. The cells were then washed twice with PBS and exposed to UVB in PBS containing the test material. UVB treatment was conducted under a cell culture hood using a UVB lamp (Model UVB-18, ULTRA*LUM. Inc., Claremont, CA, USA) that emitted radiation in the wavelength range of 280 to $340 \mathrm{~nm}$ with maximum intensity at $300 \mathrm{~nm}$. The intensity of radiation was determined using a UV light meter (Model UV 340A, Lutron Electronic Enterprise Co., Taipei, Taiwan), and the UV was administered to cells in culture plates at an intensity of $80 \mu \mathrm{W} \mathrm{cm}{ }^{-2}$. However, durations of treatment varied to provide specific doses of $\operatorname{UVB}\left(5,10\right.$, or $\left.15 \mathrm{~mJ} \mathrm{~cm}{ }^{-2}\right)$. Following irradiation, PBS was replaced by growth medium and cells were incubated for 1 day. Cells were subjected to various tests as detailed below. Culture conditioned medium was harvested and used to treat human dermal fibroblasts.

2.6. Cell Viability Test. Cell viability was assayed using 3[4,5-dimethylthiazol-2-yl]-2,5-diphenyltetrazolium bromide (MTT). This assay method is based on the ability of mitochondrial dehydrogenase in viable cells to reduce pale yellow MTT to dark blue formazan crystals that accumulate within cells. Briefly, cells were washed with PBS and incubated in $1 \mathrm{~mL}$ of culture media supplemented with $1 \mathrm{mg} \mathrm{mL}^{-1} \mathrm{MTT}$ for $3 \mathrm{~h}$. The medium was then discarded and cells were treated with isopropanol to solubilize the formazan. Solutions were then transferred to microplates and formazan was quantified by measuring absorbance at $595 \mathrm{~nm}$.

2.7. Quantitative Polymerase Chain Reaction ( $q R T-P C R)$ Analysis. Total cellular RNA was extracted using the RNeasy kit (Qiagen, Valencia, CA, USA). To prepare cDNA, one $\mu \mathrm{g}$ of cellular mRNA was reverse transcribed using the High Capacity cDNA Archive Kit (Applied Biosystems, Foster City, CA, USA). This kit utilizes random hexamers primers and MultiScribe Reverse Transcriptase. PCR was conducted using 


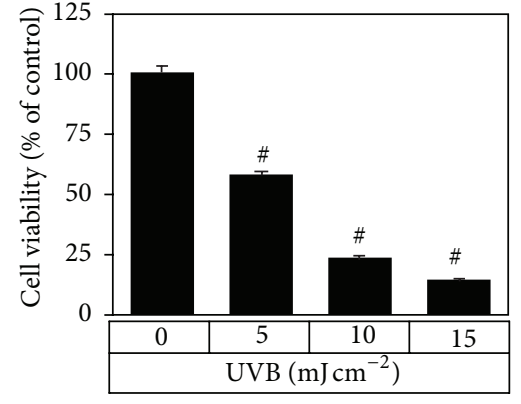

(a)

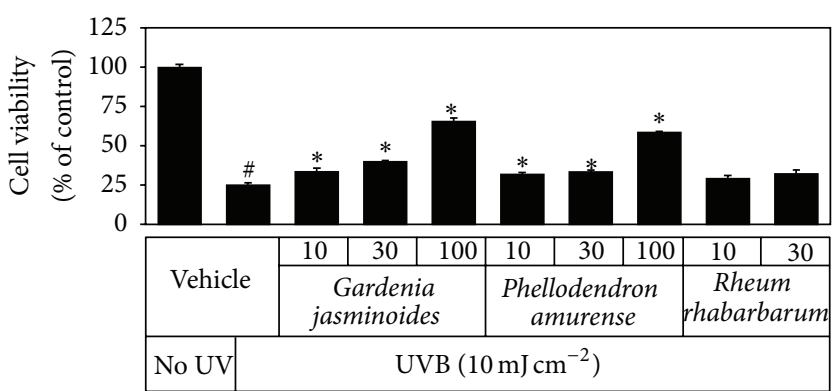

(b)

Figure 3: Effects of plant extracts on UVB cytotoxicity in HaCaT cells. In (a), HaCaT cells were irradiated with $5 \sim 15 \mathrm{~mJ} \mathrm{~cm}^{-2} \mathrm{UVB}$. In (b), cells were irradiated with $10 \mathrm{~mJ} \mathrm{~cm}{ }^{-2} \mathrm{UVB}$ in PBS in the absence or presence of plant extracts $\left(10,30\right.$, or $\left.100 \mu \mathrm{g} \mathrm{mL}^{-1}\right)$. Irradiated cells were subsequently incubated for $24 \mathrm{~h}$ and cell viabilities were determined using an MTT assay. Cell viabilities are presented as percentages of the vehicle control (means \pm SEs, $n=3$ ). ${ }^{\#} P<0.05$ versus the unirradiated control. ${ }^{*} P<0.05$ versus the vehicle control irradiated with UVB.

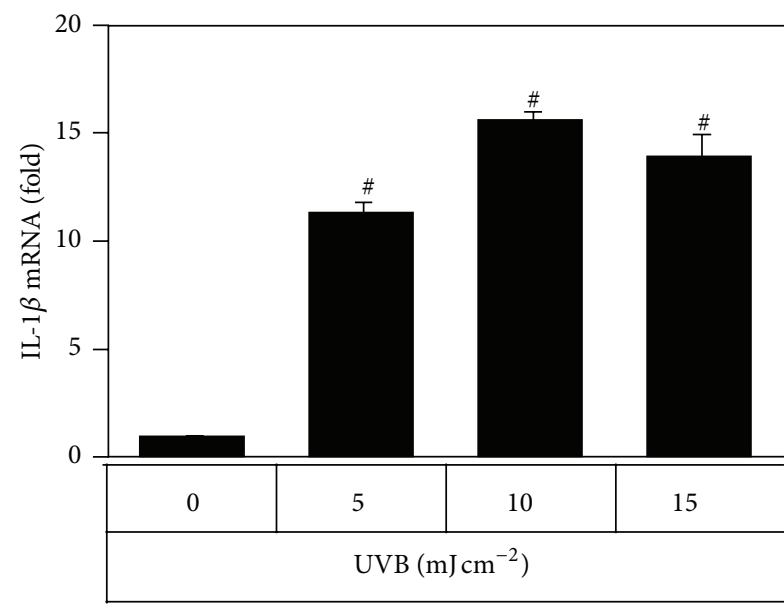

(a)

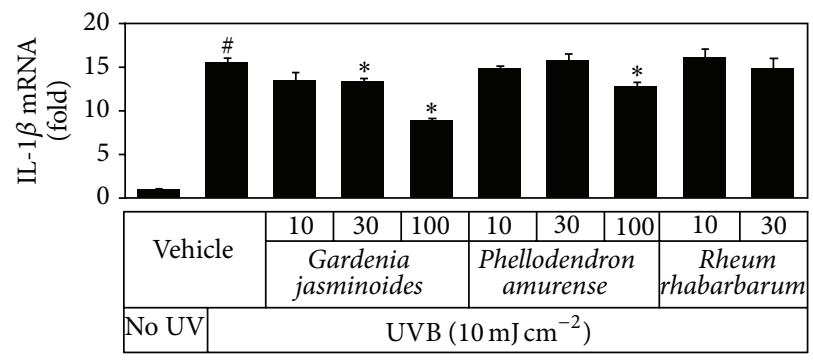

(c)

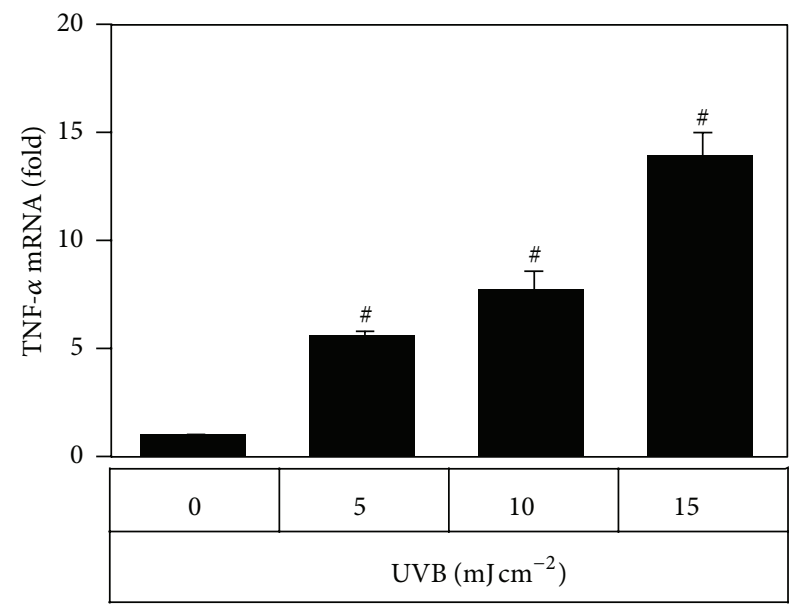

(b)

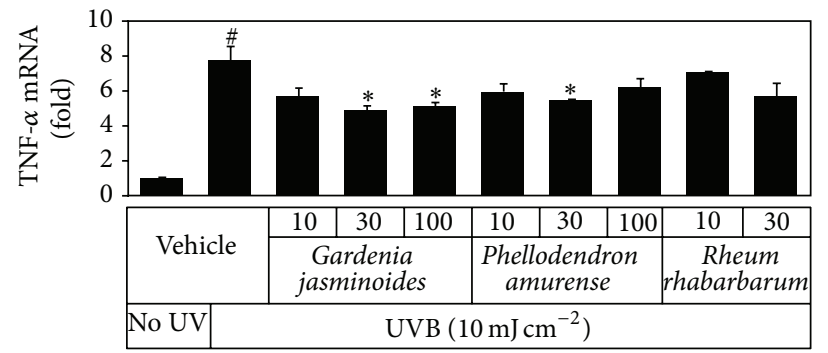

(d)

FIGURE 4: Effects of plant extracts on mRNA expressions of inflammatory cytokines induced by UVB in HaCaT cells. In (a) and (b), HaCaT

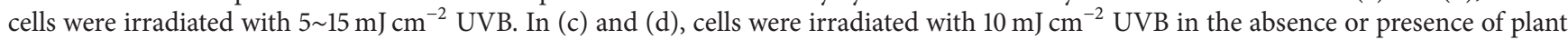
extracts $\left(10,30\right.$, or $\left.100 \mu \mathrm{g} \mathrm{mL} \mathrm{m}^{-1}\right)$ and then incubated for $24 \mathrm{~h}$ before mRNA analysis by qRT-PCR. GAPDH was used as the reference. Data are expressed as fold changes (means \pm SEs; $n=3$ ). ${ }^{\#} P<0.05$ versus the unirradiated control. ${ }^{*} P<0.05$ versus the vehicle control irradiated with UVB.

the StepOnePlus Real-Time PCR System (Applied Biosystems) in reaction mixtures $(20 \mu \mathrm{L})$ containing SYBR Green PCR Master Mix (Applied Biosystems), 60 ng of cDNA, and 2 picomole of gene-specific primer sets (Macrogen, Seoul). The primers used for PCR analysis were as follows: interleukin$1 \beta$ (IL-1 $\beta$ ) (GeneBank accession number: NM_000576.2)
5'-CCT GTC CTG CGT GTT GAA AGA-3' (forward) and $5^{\prime}$-GGG AAC TGG GCA GAC TCA AA-3' (reverse), tumor necrosis factor- $\alpha$ (TNF- $\alpha$ ) (NM_000594.3) $5^{\prime}$-TGC TCC TCA CCC ACA CCA T-3' (forward) and $5^{\prime}-\mathrm{GAG}$ ATA GTC GGG CCG ATT GA-3' (reverse), and GAPDH (NM_002046.3) 5'-ATG GGG AAG GTG AAG GTC G-3' 


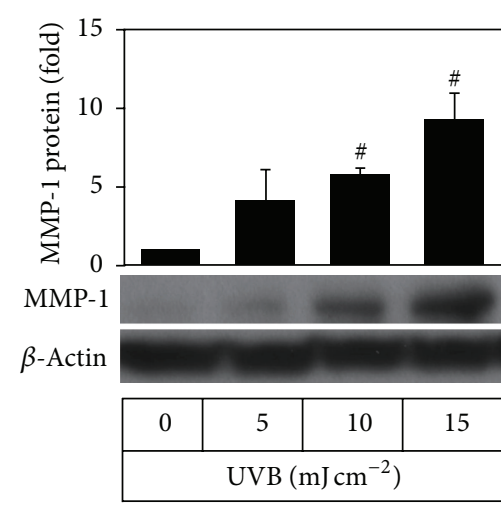

(a)

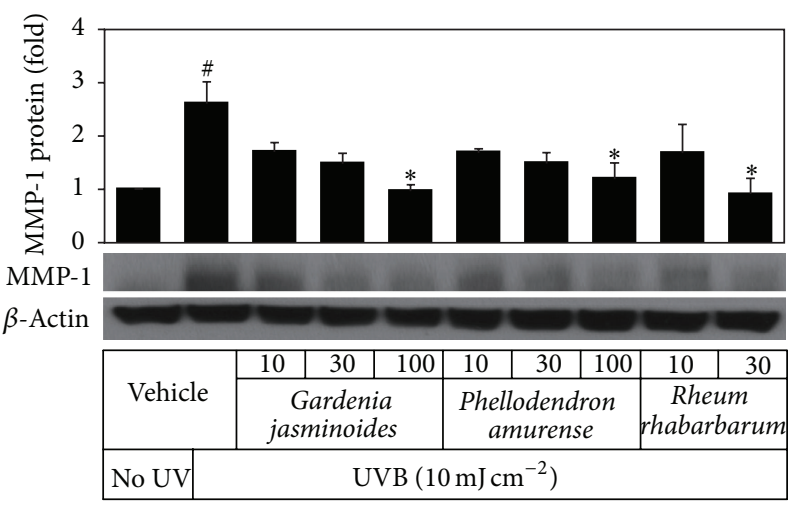

(b)

Figure 5: Expression levels of MMP-1 protein in human dermal fibroblasts stimulated by the conditioned media of HaCaT cells irradiated with UVB in the absence or presence of plant extracts. In (a), HaCaT cells were irradiated with UVB at $5 \sim 15 \mathrm{~mJ} \mathrm{~cm}^{-2}$ and then incubated for $24 \mathrm{~h}$. The conditioned medium from the UVB-irradiated HaCaT cells was used to treat human dermal fibroblasts for $24 \mathrm{~h}$. In (b), HaCaT cells were irradiated with UVB at $10 \mathrm{~mJ} \mathrm{~cm}^{-2}$ in PBS containing plant extracts at various concentrations $\mu \mathrm{g} \mathrm{mL}^{-1}$ and then incubated for $24 \mathrm{~h}$. Conditioned media from these UVB-irradiated $\mathrm{HaCaT}$ cells were used to treat human dermal fibroblasts for $24 \mathrm{~h}$. MMP-1 protein expressions in fibroblasts were analyzed by Western blot using $\beta$-actin as a loading control. Typical blot images are shown. Data are expressed as fold changes (means \pm SEs; $n=3$ ). ${ }^{\#} P<0.05$ versus the unirradiated control. ${ }^{*} P<0.05$ versus the vehicle control irradiated with UVB.

(forward) and $5^{\prime}$-GGG GTC ATT GAT GGC AAC AA-3' (reverse). Reactions were performed using the following conditions: $50^{\circ} \mathrm{C}$ for $2 \mathrm{~min}, 95^{\circ} \mathrm{C}$ for $10 \mathrm{~min}$, and 40 amplification cycles $\left(95^{\circ} \mathrm{C}\right.$ for $15 \mathrm{~s}$ and $60^{\circ} \mathrm{C}$ for $\left.1 \mathrm{~min}\right)$, followed by a dissociation step. Melting curve analysis showed single peaks, which supported the homogeneity of amplicons. The mRNA expression levels of IL- $1 \beta$ and TNF- $\alpha$ relative to that of internal control, glyceraldehyde 3-phosphate dehydrogenase $(\mathrm{GAPDH})$, were calculated using the comparative threshold cycle (CT) method.

2.8. Culture of Human Dermal Fibroblasts. Human dermal fibroblasts isolated from adult skin were obtained from Cascade Biologics (Portland, OR, USA). The cells were cultured at $37^{\circ} \mathrm{C}$ in a humidified atmosphere containing $5 \% \mathrm{CO}_{2}$ and 95\% air in growth medium (Iscove's Modified Dulbecco's medium (GIBCO-BRL, Grand Island, NY, USA) containing $10 \%$ fetal bovine serum, $100 \mathrm{U} \mathrm{mL}^{-1}$ penicillin, $0.1 \mathrm{mg} \mathrm{mL}^{-1}$ streptomycin, and $0.25 \mu \mathrm{g} \mathrm{mL}^{-1}$ amphotericin B). In experiments on the paracrine effects of factors secreted by keratinocytes, the medium was completely replaced by the conditioned medium of UVB-irradiated HaCaT cells, and fibroblasts were cultivated for $24 \mathrm{~h}$ before analysis.

2.9. Western Blotting. Whole cell lysates were prepared using a lysis buffer (10 mM Tris-Cl, pH 7.4, $120 \mathrm{mM} \mathrm{NaCl,} 25 \mathrm{mM}$ $\mathrm{KCl}, 2$ mM EGTA, $1 \mathrm{mM}$ EDTA, 0.5\% Triton X-100, and protease inhibitor cocktail). Aliquots of lysates were subjected to sodium dodecyl sulfate polyacrylamide gel electrophoresis (SDS-PAGE) under protein denaturing conditions. Proteins separated were transferred to polyvinylidene fluoride membranes, which were incubated with an appropriate primary antibody overnight at $4^{\circ} \mathrm{C}$ and then with a secondary antibody conjugated to horseradish peroxidase for $1 \mathrm{~h}$ at room temperature. Immunoreactive bands were detected using a picoEPD Western Reagent kit (ELPIS-Biotech, Daejeon, Korea) and subjected to densitometric analysis. The primary antibody for MMP-1 was purchased from Calbiochem (San Diego, CA, USA). Rabbit polyclonal caspase-3 antibody and rabbit polyclonal caspase-9 were purchased from Cell Signaling (Danvers, MA, USA). The mouse monoclonal $\beta$ actin antibody was from Sigma-Aldrich (St. Louis, MO, USA).

2.10. Analysis of Lipid Peroxidation. As a marker of lipid peroxidation, 2-thiobarbituric acid-reactive substances (TBARS) were quantified [19]. Briefly, cells were treated in a lysis buffer (20 mM Tris-Cl, 2.5 mM EDTA, 1.0\% SDS, pH 7.5). Cell lysates $(200 \mathrm{mg}$ protein in $100 \mu \mathrm{L})$ were mixed with $900 \mu \mathrm{L}$ of $1.0 \%$ phosphoric acid and $1.0 \mathrm{~mL}$ of $0.9 \% 2$ thiobarbituric acid (Sigma-Aldrich) and then heated on a boiling water bath for $45 \mathrm{~min}$. Standard solutions of 1,1,3,3tetramethoxypropane (Sigma-Aldrich), a precursor of malondialdehyde, were treated in the same way as cell lysates. After cooling, $1.5 \mathrm{~mL}$ of 1-butanol was added and the mixture was centrifuged at 13,000 rpm for $15 \mathrm{~min}$ to separate into two layers. The fluorescence intensity of the 1-butanol layer was measured at an emission wavelength of $590 \mathrm{~nm}$ (excitation at $540 \mathrm{~nm}$ ) using the Gemini EM fluorescence microplate reader (Molecular Devices, Sunnyvale, CA, USA).

2.11. Statistical Analysis. Data are presented as the means \pm SEs of three or more independent experiments. The significance of differences between groups was determined using the Student's $t$-test. Duncan's multiple-range test was applied when differences were significant $(P<0.05)$ by the Student's $t$-test. Statistical significance was accepted for $P$ values $<0.05$. 

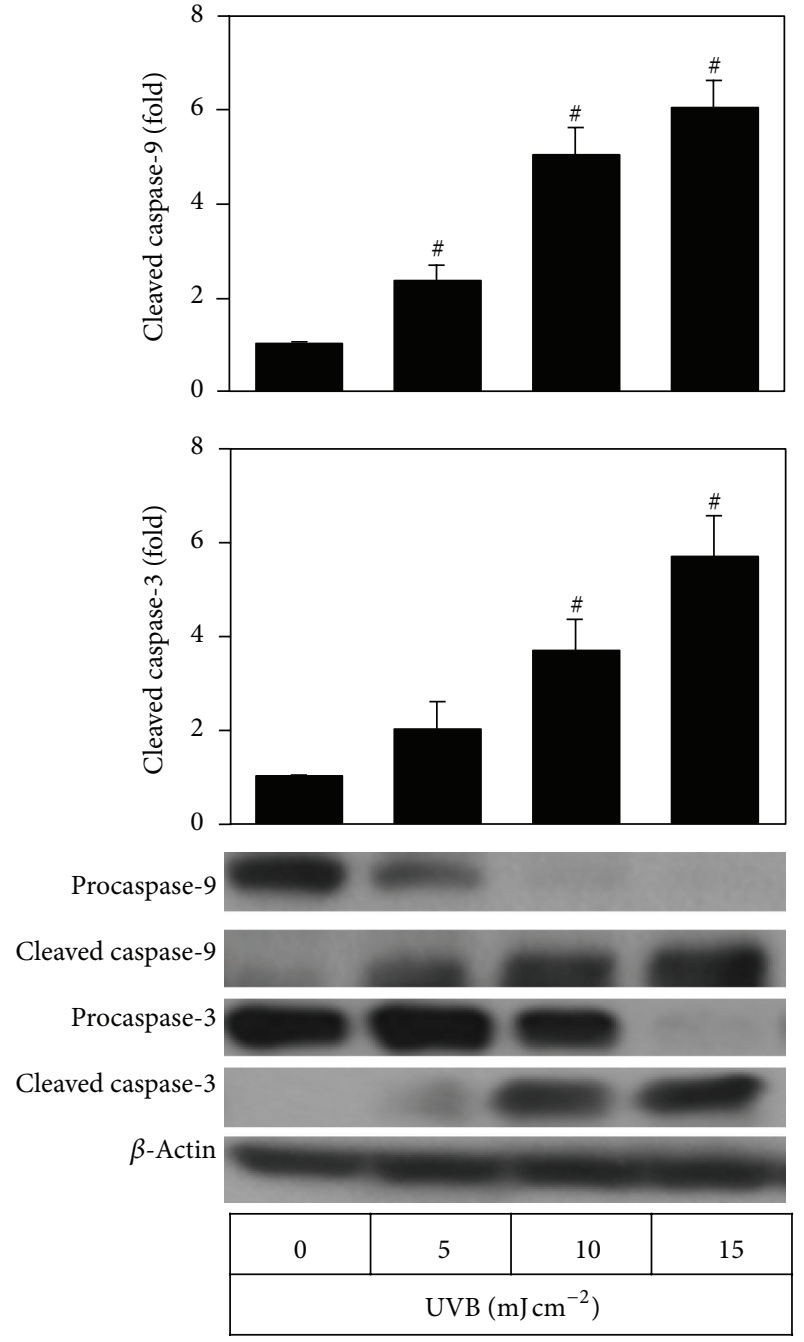

(a)
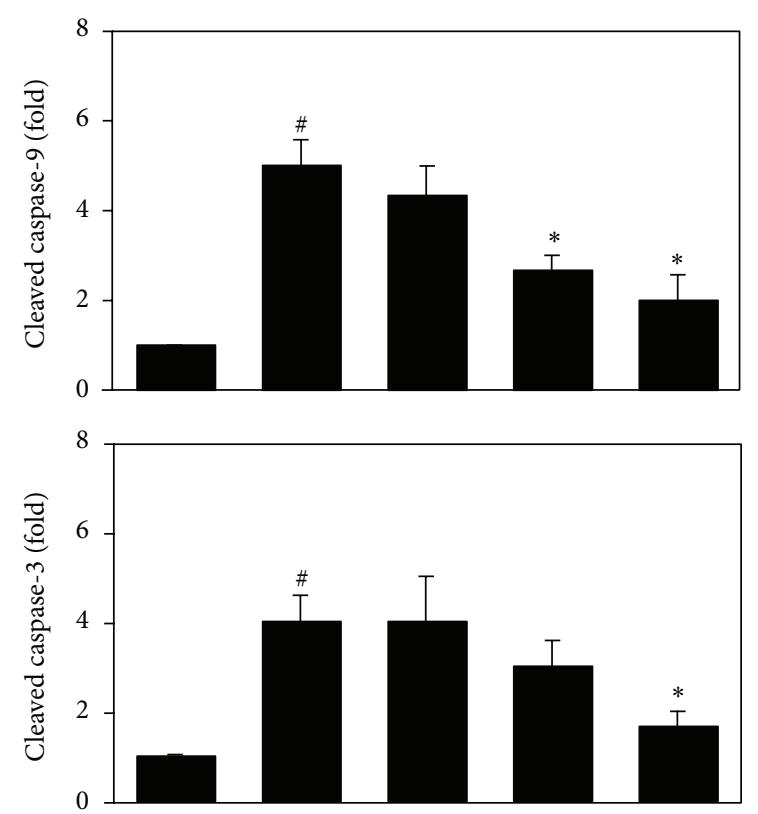

Procaspase- 9

Cleaved caspase- 9

Procaspase-3

Cleaved caspase-3

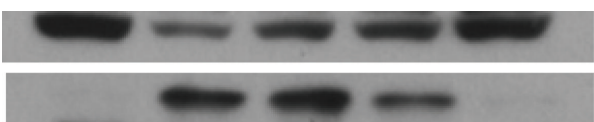

$$
\beta \text {-Actin }
$$
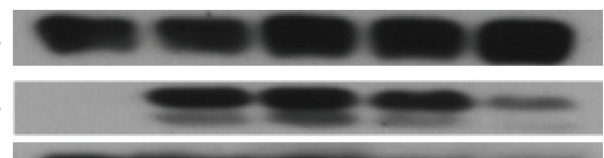

\begin{tabular}{|c|c|c|c|}
\hline \multirow{2}{*}{ Vehicle } & 10 & 30 & 100 \\
\hline & \multicolumn{3}{|c|}{ Gardenia jasminoides } \\
\hline No UV & \multicolumn{3}{|c|}{$\mathrm{UVB}\left(10 \mathrm{~mJ} \mathrm{~cm}^{-2}\right)$} \\
\hline
\end{tabular}

(b)

FIgURE 6: Effects of Gardenia jasminoides extract on caspase-9 and caspase-3 in HaCaT cells exposed to UVB radiation. In (a), HaCaT cells were irradiated with $5 \sim 15 \mathrm{~mJ} \mathrm{~cm}^{-2}$ UVB. In (b), cells were irradiated with $10 \mathrm{~mJ} \mathrm{~cm} \mathrm{~cm}^{-2} \mathrm{UVB}$ in the absence or presence of Gardenia jasminoides extract $\left(10,30\right.$, or $\left.100 \mu \mathrm{g} \mathrm{mL}^{-1}\right)$ and then incubated for $24 \mathrm{~h}$. The cleavage of procaspase- 9 and procaspase-3 to their cleaved active forms was analyzed by Western blot. Data are expressed as fold changes (means \pm SEs; $n=3$ ). ${ }^{\#} P<0.05$ versus the unirradiated control. ${ }^{*} P<0.05$ versus the vehicle control irradiated with UVB.

\section{Results}

The absorption spectra of the extracts of Gardenia jasminoides, Phellodendron amurense, and Rheum rhabarbarum were measured at $10 \sim 100 \mu \mathrm{g} \mathrm{mL}^{-1}$. As shown in Figure 1, these extracts showed similar absorptivities in the UVB region $(280 \sim 320 \mathrm{~nm})$, and Gardenia jasminoides extract showed the highest absorption in the UVA $(320 \sim 400 \mathrm{~nm})$ and blue light region. The cytotoxicities of extracts were compared by treating $\mathrm{HaCaT}$ human keratinocytes at $10 \sim$ $100 \mu \mathrm{g} \mathrm{mL}^{-1}$ for $24 \mathrm{~h}$. As shown in Figure 2, Gardenia jasminoides extract appeared to be nontoxic up to $100 \mu \mathrm{g} \mathrm{mL}^{-1}$, whereas Phellodendron amurense extract was mildly cytotoxic at this concentration and Rheum rhabarbarum was cytotoxic at concentrations above $30 \mu \mathrm{g} \mathrm{mL}^{-1}$.
The protective effects of the plant extracts against UVBinduced cell death were then examined. First, HaCaT cells were exposed to $5 \sim 15 \mathrm{~mJ} \mathrm{~cm}^{-2}$ and incubated for $24 \mathrm{~h}$, and changes in cell viability were determined. As shown in Figure 3(a), HaCaT cell viability was reduced by UV exposure in a dose-dependent manner. Cells were then exposed to $\mathrm{UVB}$ at $10 \mathrm{~mJ} \mathrm{~cm}{ }^{-2}$ in the presence of different concentrations of plant extracts, and cell viabilities were assessed $24 \mathrm{~h}$ later. As shown in Figure 3(b), Gardenia jasminoides extract dosedependently increased the viabilities of UVB-exposed cells. Phellodendron amurense extract was also found to have a smaller cytoprotective effect, but Rheum rhabarbarum extract had no observable effects.

The effects of plant extracts on inflammatory cytokine expression were examined in HaCaT cells exposed to UVB 


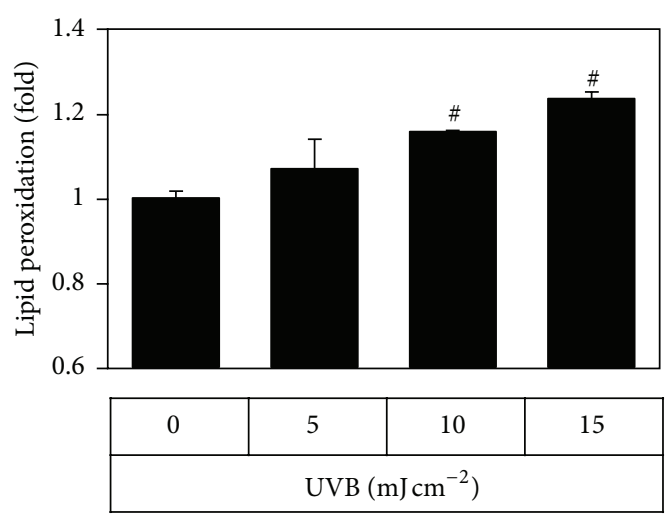

(a)

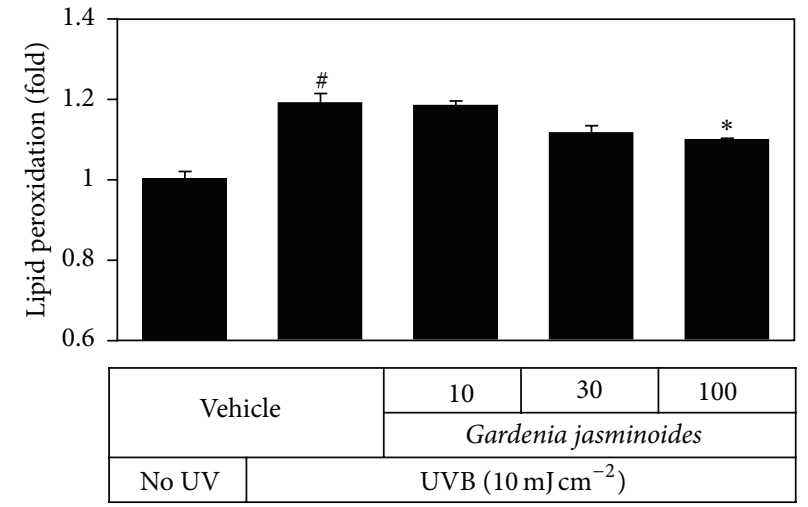

(b)

FIGURE 7: Effects of Gardenia jasminoides extract on UVB-induced lipid peroxidation in HaCaT cells. In (a), HaCaT cells were irradiated with $5 \sim 15 \mathrm{~mJ} \mathrm{~cm}^{-2}$ UVB. In (b), cells were irradiated with $10 \mathrm{~mJ} \mathrm{~cm} \mathrm{c}^{-2} \mathrm{UVB}$ in the absence or presence of Gardenia jasminoides extract (10, 30, or $100 \mu \mathrm{g} \mathrm{mL}^{-1}$ ) and then incubated for $24 \mathrm{~h}$. Lipid peroxidation was determined by quantifying TBARS. Data are expressed as fold changes (means \pm SEs; $n=3$ ). Control value was 0.33 nmol TBARS per mg protein. ${ }^{*} P<0.05$ versus the unirradiated control. ${ }^{*} P<0.05$ versus the vehicle control irradiated with UVB.

at $5 \sim 15 \mathrm{~mJ} \mathrm{~cm}^{-2}$ and incubated for $24 \mathrm{~h}$. Total cellular mRNA was extracted and the mRNA levels of cytokines were determined by quantitative Real-Time PCR. As shown in Figure 4(a), UVB increased the mRNA expressions of IL- $1 \beta$ and TNF- $\alpha$ markedly. Cells were then exposed to UVB at $10 \mathrm{~mJ} \mathrm{~cm}^{-2}$ in the presence of plant extracts at different concentrations. It was found that Gardenia jasminoides extract at $30 \sim 100 \mu \mathrm{g} \mathrm{mL}^{-1}$ attenuated inflammatory cytokine expression in $\mathrm{HaCaT}$ cells exposed to UVB, and Phellodendron amurense extract showed a smaller effect.

Because UVB increased inflammatory cytokine expression in $\mathrm{HaCaT}$ cells, we examined whether the conditioned medium of UVB-exposed HaCaT keratinocytes, which contained inflammatory cytokines, stimulated MMP-1 expression in fibroblasts via paracrine effects. When conditioned medium from $\mathrm{HaCaT}$ cells exposed to different doses of UVB was added to human dermal fibroblasts cultures and cultured for $24 \mathrm{~h}, \mathrm{MMP}-1$ expressions in fibroblasts were found to increase in a UVB dose-dependent manner (Figure 5(a)). We then examined the effects of plant extracts on the paracrine effects of cytokines secreted by UVB-exposed HaCaT keratinocytes on MMP-1 expression in fibroblasts. As shown in Figure 5(b), the presence of plant extracts such as Gardenia jasminoides extract during UVB exposure of $\mathrm{HaCaT}$ cells rendered the conditioned medium less effective in increasing MMP-1 expression in fibroblasts.

Apoptotic cell death is also known as one of the major mechanisms of photoaging of the skin [20]. Because caspase9 and caspase-3 are known to be critical players in UVinduced apoptosis in keratinocytes [21], we examined the effect of Gardenia jasminoides extract on the activation of these apoptosis mediator enzymes in $\mathrm{HaCaT}$ cells exposed to UVB. As expected, UVB irradiation increased cleavage of procaspase- 9 and procaspase- 3 to their cleaved active forms in a UVB dose-dependent manner (Figure 6(a)). It was also observed that the UVB-induced increases of cleaved caspase- 9 and cleaved caspase- 3 were markedly prevented when Gardenia jasminoides extract was included in the medium (Figure 6(b)).

UV can also induce oxidative stress in cells by stimulating overproduction of reactive oxygen species (ROS) and depleting antioxidants $[22,23]$. In the current study, we determined the levels of TBARS to monitor lipid peroxidation [19]. The results showed that lipid peroxidation increased in HaCaT cells exposed to UVB (Figure 7(a)) and this change was attenuated by Gardenia jasminoides extract in a dosedependent manner (Figure 7(b)).

Typical HPLC patterns of the extracts of Gardenia jasminoides, Phellodendron amurense, and Rheum rhabarbarum are shown in Figure 8. Commercially sourced crocin was used as a reference compound because it is known as a major pigment in Gardenia jasminoides [24]. The content of crocin in Gardenia jasminoides extract was estimated to be $1.7 \%$. It was not detected in the extract of Phellodendron amurense or Rheum rhabarbarum.

\section{Discussion}

$\mathrm{UV}$ is a major cause of skin photoaging and photocarcinogenesis [25]. UV consists of UVA (320 400 nm), UVB (280 $320 \mathrm{~nm})$, and UVC (200 280 $\mathrm{nm})$, and overexposure to UV, particularly the UVB component, causes erythema, edema, hyperplasia, hyperpigmentation, photoaging, immunosuppression, and skin cancer $[2,26]$. Overexposure to UV also causes oxidative stress as evidenced by increased lipid peroxidation and by the depletion of cutaneous antioxidants $[27,28]$. Previous studies have demonstrated the preventive effects of exogenous antioxidants on photocarcinogenesis [29]. Plant extracts are attractive cosmeceuticals because some are rich in secondary metabolites that provide UVBscreening, antioxidative, and anti-inflammatory activities. The results of the current study indicate that yellow-colored plant extracts like Gardenia jasminoides extract have potential 


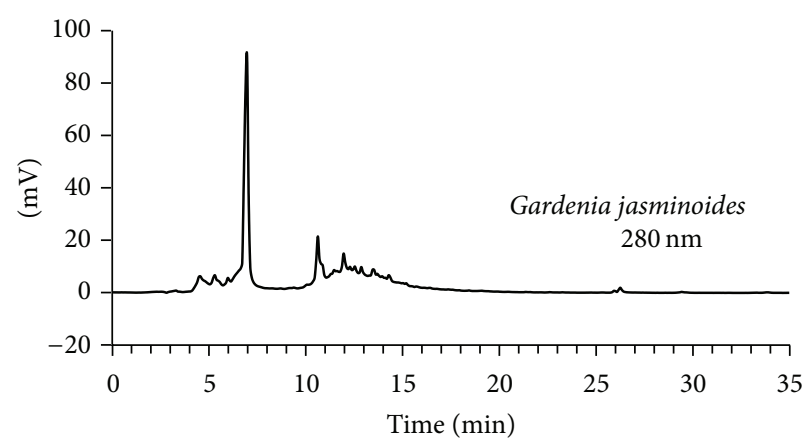

(a)

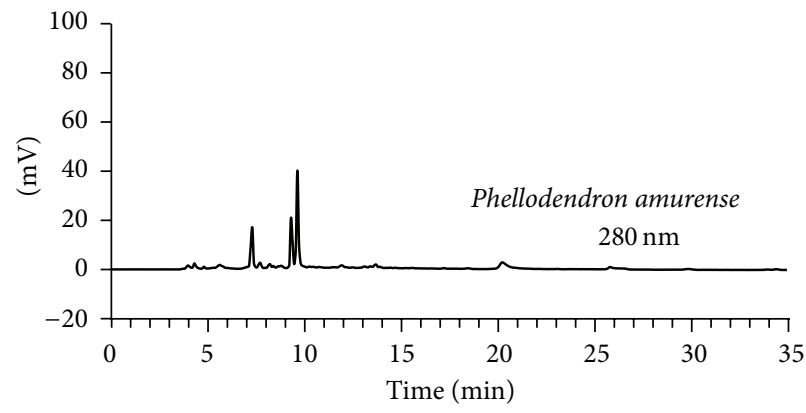

(b)

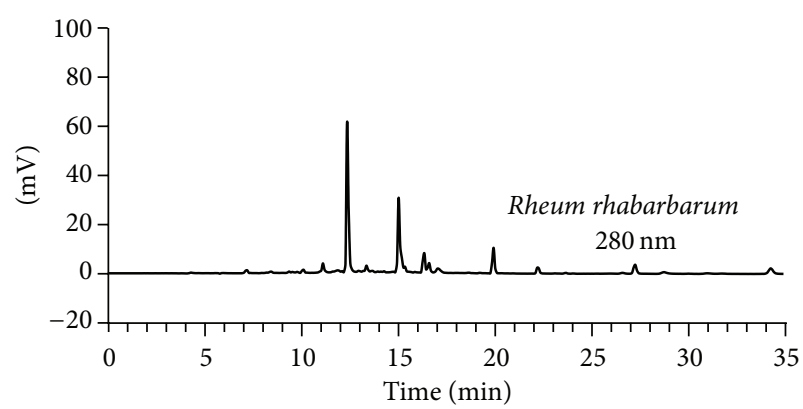

(c)

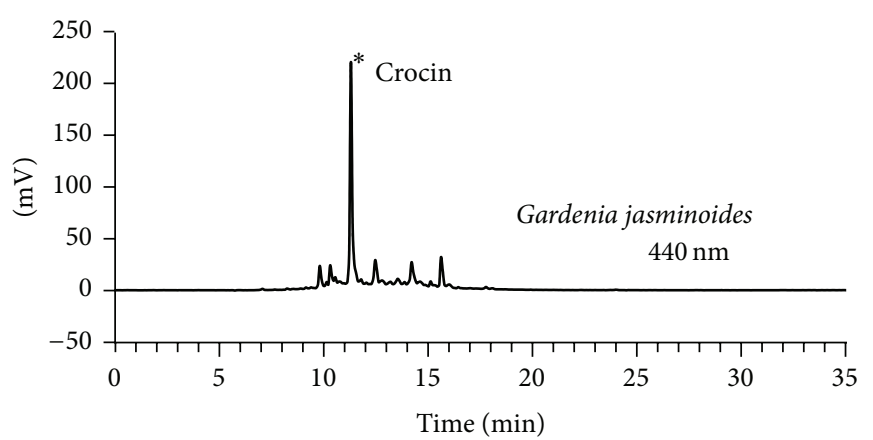

(d)

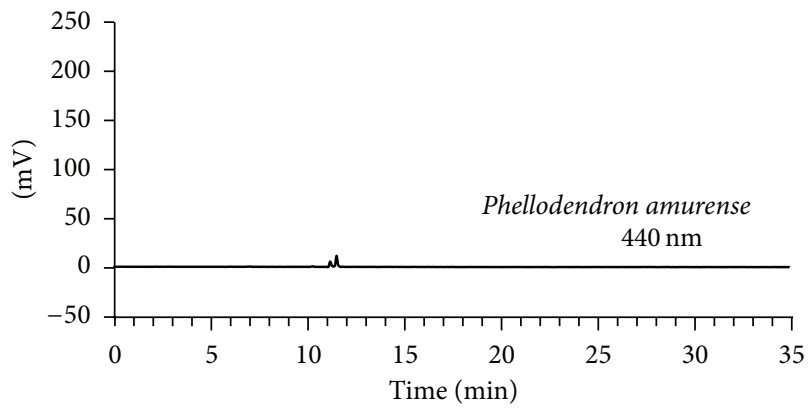

(e)

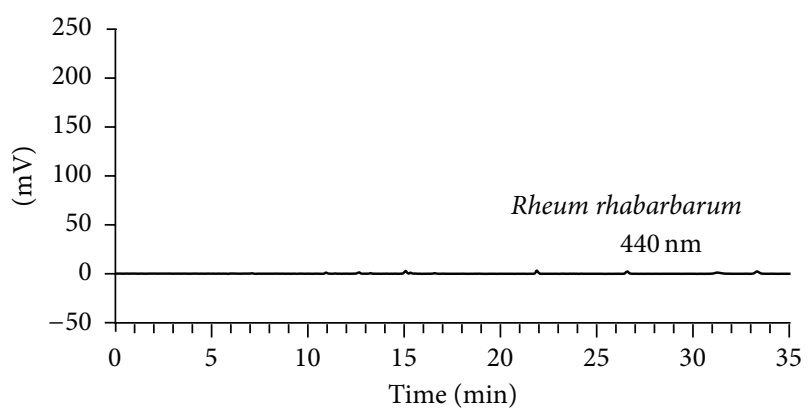

(f)

FIgURE 8: Fingerprint HPLC of plant extracts from Gardenia jasminoides, Phellodendron amurense, and Rheum rhabarbarum. Typical HPLC chromatograms at $280 \mathrm{~nm}(\mathrm{a}, \mathrm{b}, \mathrm{c})$ and $440 \mathrm{~nm}(\mathrm{~d}, \mathrm{e}, \mathrm{f})$ are shown. The peak of crocin was assigned by cochromatography with commercially sourced crocin.

use as cosmeceuticals to attenuate the deleterious effects of UV exposure.

Compared to the extracts of Phellodendron amurense and Rheum rhabarbarum, Gardenia jasminoides extract was found to absorb a wider range of UV (Figure 1) and to have minimal effects on the viability of $\mathrm{HaCaT}$ cells cultured in vitro (Figure 2). In addition, Gardenia jasminoides extract attenuated the viability loss of HaCaT cells caused by UVB exposure (Figure 3). Under our experimental conditions, cells were treated with the plant extract in PBS while being exposed to UVB to minimize the UV screening effects of other factors. Thus, we attributed the cytoprotective effect of Gardenia jasminoides extract to its UV shielding effects.

Keratinocytes constitute $95 \%$ of the mass of human epidermis cells and play critical roles in skin physiology due to their autocrine and paracrine effects [30]. The constitutive productions of cytokines and other soluble factors are low in human keratinocytes, but various stimuli, including endotoxins and UV, can trigger the expression of proinflammatory cytokines [31]. In the present study, UVB exposure increased the expressions of IL- $1 \beta$ and TNF- $\alpha$ markedly in HaCaT cells, as was expected (Figure 4). In addition, these changes were significantly attenuated by the presence of plant extracts during UV exposure (Figure 4). These results indicate that plant extracts, such as Gardenia jasminoides extract, can attenuate cytokine expression in keratinocytes.

MMP-1 expression in human dermal fibroblasts increased when these cells were treated with the conditioned medium from UVB-irradiated HaCaT cells (Figure 5(a)). These results suggest that certain cytokines or cell components from UVBirradiated keratinocytes can regulate MMP-1 expression in fibroblasts through paracrine effects. Cytokines such as IL$1 \beta$ and TNF- $\alpha$ are known to stimulate MMP- 1 expression in 
fibroblasts [32], other factors such as stratifin also could play a role $[15,33]$. Nonetheless, Gardenia jasminoides extract attenuated these paracrine effects in a dose-dependent manner (Figure 5(b)), which was in line with its effects on cytokine expressions in $\mathrm{HaCaT}$ cells (Figure 4).

UV can induce apoptosis of keratinocytes via intrinsic pathways involving direct DNA damage, extrinsic pathways involving activated cell membrane death receptors, and generation of $\operatorname{ROS}[20,21]$. Occurrence of apoptosis can be monitored by using various markers including DNA laddering, changes of proapoptotic (Bax, Bak, and Bid) and antiapoptotic ( $\mathrm{Bcl}-2$ and $\mathrm{Bcl}-\mathrm{x})$ members of the $\mathrm{Bcl}-2$ protein family, activation of caspases, and so on. In the present study, we observed UVB dose-dependent increases in cleaved active forms of caspase- 9 and caspase- 3 and attenuation of these changes by Gardenia jasminoides extract (Figure 6). In addition, Gardenia jasminoides extract was observed to attenuate UVB-induced oxidative stress, as monitored by lipid peroxidation (Figure 7). Therefore, Gardenia jasminoides extract was considered to be useful in protecting skin cells from UV-induced oxidative stress, inflammation, and apoptotic death.

Gardenia jasminoides belongs to the botanical family Rubiaceae and is found in South Asia. Gardenia jasminoides fruits have been traditionally used in oriental medicine to treat jaundice, fever, hypertension, and skin ulcers. Its yellow pigment has been used as a natural food colorant and dye. The major constituent of this yellow pigment is crocin, a water soluble carotenoid derivative [24], and the pharmacological effects of crocin, and of its aglycone crocetin, have been widely investigated $[34,35]$. The protective effects of Gardenia jasminoides extract against UVB-induced injury and inflammatory responses of skin cells might be attributed to the UV shielding effect of crocin (Figures 1 and 8).

\section{Conclusion}

In conclusion, this study suggests that UVB-induced oxidative stress, apoptotic cell death, and inflammatory responses of skin cells can be attenuated by yellow-colored plant extracts, such as Gardenia jasminoides extract, that absorb UV effectively, and these extracts are useful cosmetic ingredients.

\section{Conflict of Interests}

The authors declare that there is no conflict of interests regarding the publication of this paper.

\section{Acknowledgments}

This study was supported by a grant (Grant no. A103017) from the Korea Health Technology R\&D Project, Ministry of Health and Welfare and by a grant (Grant no. R0002039) from the Regional Specialized Technology Convergence Project, Ministry of Trade, Industry and Energy, Republic of Korea.

\section{References}

[1] C. Antoniou, M. G. Kosmadaki, A. J. Stratigos, and A. D. Katsambas, "Photoaging: prevention and topical treatments," American Journal of Clinical Dermatology, vol. 11, no. 2, pp. 95102,2010

[2] G.-E. Costin and V. J. Hearing, "Human skin pigmentation: melanocytes modulate skin color in response to stress," FASEB Journal, vol. 21, no. 4, pp. 976-994, 2007.

[3] K. Scharffetter-Kochanek, P. Brenneisen, J. Wenk et al., "Photoaging of the skin from phenotype to mechanisms," Experimental Gerontology, vol. 35, no. 3, pp. 307-316, 2000.

[4] V.-M. Kähäri and U. Saarialho-Kere, "Matrix metalloproteinases in skin," Experimental Dermatology, vol. 6, no. 5, pp. 199-213, 1997.

[5] W. Bode, C. Fernandez-Catalan, H. Tschesche, F. Grams, H. Nagase, and K. Maskos, "Structural properties of matrix metalloproteinases," Cellular and Molecular Life Sciences, vol. 55, no. 4, pp. 639-652, 1999.

[6] K. Scharffetter, M. Wlaschek, A. Hogg et al., "UVA irradiation induces collagenase in human dermal fibroblasts in vitro and in vivo," Archives of Dermatological Research, vol. 283, no. 8, pp. 506-511, 1991.

[7] P. Brenneisen, J. Oh, M. Wlaschek et al., "Ultraviolet B wavelength dependence for the regulation of two major matrixmetalloproteinases and their inhibitor TIMP-1 in human dermal fibroblasts," Photochemistry and Photobiology, vol. 64, no. 5, pp. 877-885, 1996.

[8] S. Pillai, C. Oresajo, and J. Hayward, "Ultraviolet radiation and skin aging: roles of reactive oxygen species, inflammation and protease activation, and strategies for prevention of inflammation-induced matrix degradation-a review," International Journal of Cosmetic Science, vol. 27, no. 1, pp. 17-34, 2005.

[9] G. J. Fisher, S. Kang, J. Varani et al., "Mechanisms of photoaging and chronological skin aging," Archives of Dermatology, vol. 138, no. 11, pp. 1462-1470, 2002.

[10] G. J. Fisher, H. S. Talwar, J. Lin et al., "Retinoic acid inhibits induction of c-Jun protein by ultraviolet radiation that occurs subsequent to activation of mitogen-activated protein kinase pathways in human skin in vivo," Journal of Clinical Investigation, vol. 101, no. 6, pp. 1432-1440, 1998.

[11] P. Brenneisen, H. Sies, and K. Scharffetter-Kochanek, "Ultraviolet-B irradiation and matrix metalloproteinases: from induction via signaling to initial events," Annals of the New York Academy of Sciences, vol. 973, pp. 31-43, 2002.

[12] J. Westermarck and V.-M. Kähäri, "Regulation of matrix metalloproteinase expression in tumor invasion," FASEB Journal, vol. 13, no. 8, pp. 781-792, 1999.

[13] K. K. Dong, N. Damaghi, S. D. Picart et al., "UV-induced DNA damage initiates release of MMP-1 in human skin," Experimental Dermatology, vol. 17, no. 12, pp. 1037-1044, 2008.

[14] D. Fagot, D. Asselineau, and F. Bernerd, "Matrix metalloproteinase-1 production observed after solar-simulated radiation exposure is assumed by dermal fibroblasts but involves a paracrine activation through epidermal keratinocytes," Photochemistry and Photobiology, vol. 79, no. 6, pp. 499-505, 2004.

[15] D. Fagot, D. Asselineau, and F. Bernerd, "Direct role of human dermal fibroblasts and indirect participation of epidermal keratinocytes in MMP-1 production after UV-B irradiation," Archives of Dermatological Research, vol. 293, no. 11, pp. 576$583,2002$. 
[16] S. K. Katiyar, N. J. Korman, H. Mukhtar, and R. Agarwal, "Protective effects of silymarin against photocarcinogenesis in a mouse skin model," Journal of the National Cancer Institute, vol. 89, no. 8, pp. 556-566, 1997.

[17] N. Cole, P. W. Sou, A. Ngo et al., “Topical “Sydney” propolis protects against UV-radiation-induced inflammation, lipid peroxidation and immune suppression in mouse skin," International Archives of Allergy and Immunology, vol. 152, no. 2, pp. 87-97, 2010.

[18] L. V. Jørgensen, H. J. Andersen, and L. H. Skibsted, "Kinetics of reduction of hypervalent iron in myoglobin by crocin in aqueous solution," Free Radical Research, vol. 27, no. 1, pp. 73-87, 1997.

[19] M. Uchiyama and M. Mihara, "Determination of malonaldehyde precursor in tissues by thiobarbituric acid test," Analytical Biochemistry, vol. 86, no. 1, pp. 271-278, 1978.

[20] C. H. Lee, S. B. Wu, C. H. Hong, H. S. Yu, and Y. H. Wei, "Molecular mechanisms of UV-induced apoptosis and its effects on skin residential cells: the implication in UV-based phototherapy," International Journal of Molecular Sciences, vol. 14, no. 3, pp. 6414-6435, 2013.

[21] L. A. Sitailo, S. S. Tibudan, and M. F. Denning, "Activation of caspase-9 is required for UV-induced apoptosis of human keratinocytes," Journal of Biological Chemistry, vol. 277, no. 22, pp. 19346-19352, 2002.

[22] G. R. Aitken, J. R. Henderson, S.-C. Chang, C. J. McNeil, and M. A. Birch-Machin, "Direct monitoring of UV-induced free radical generation in HaCaT keratinocytes," Clinical and Experimental Dermatology, vol. 32, no. 6, pp. 722-727, 2007.

[23] M. Podda, M. G. Traber, C. Weber, L.-J. Yan, and L. Packer, "UVirradiation depletes antioxidants and causes oxidative damage in a model of human skin," Free Radical Biology and Medicine, vol. 24, no. 1, pp. 55-65, 1998.

[24] T. Watanabe and S. Terabe, "Analysis of natural food pigments by capillary electrophoresis," Journal of Chromatography A, vol. 880, no. 1-2, pp. 311-322, 2000.

[25] J. H. Epstein, "Photocarcinogenesis, skin cancer, and aging," Journal of the American Academy of Dermatology, vol. 9, no. 4, pp. 487-502, 1983.

[26] F. Afaq and H. Mukhtar, "Botanical antioxidants in the prevention of photocarcinogenesis and photoaging," Experimental Dermatology, vol. 15, no. 9, pp. 678-684, 2006.

[27] N. A. Soter, "Acute effects of ultraviolet radiation on the skin," Seminars in Dermatology, vol. 9, no. 1, pp. 11-15, 1990.

[28] F. Afaq and H. Mukhtar, "Effects of solar radiation on cutaneous detoxification pathways," Journal of Photochemistry and Photobiology B, vol. 63, no. 1-3, pp. 61-69, 2001.

[29] F. D’Agostini, R. M. Balansky, A. Camoirano, and S. de Flora, "Modulation of light-induced skin tumors by $\mathrm{N}$-acetylcysteine and/or ascorbic acid in hairless mice," Carcinogenesis, vol. 26, no. 3, pp. 657-664, 2005.

[30] B. J. Nickoloff and L. A. Turka, "Keratinocytes: key immunocytes of the integument," American Journal of Pathology, vol. 143, no. 2, pp. 325-331, 1993.

[31] M. Yoshizumi, T. Nakamura, M. Kato et al., "Release of cytokines/chemokines and cell death in UVB-irradiated human keratinocytes, HaCaT,' Cell Biology International, vol. 32, no. 11, pp. 1405-1411, 2008.

[32] K. Ohguchi, T. Itoh, Y. Akao, H. Inoue, Y. Nozawa, and M. Ito, "SIRT1 modulates expression of matrix metalloproteinases in human dermal fibroblasts," British Journal of Dermatology, vol. 163, no. 4, pp. 689-694, 2010.
[33] A. Ghahary, F. Karimi-Busheri, Y. Marcoux et al., "Keratinocytereleasable stratifin functions as a potent collagenase-stimulating factor in fibroblasts," Journal of Investigative Dermatology, vol. 122, no. 5, pp. 1188-1197, 2004.

[34] J.-D. Hsu, F.-P. I. Chou, M.-J. Lee et al., "Suppression of the TPA-induced expression of nuclear-protooncogenes in mouse epidermis by crocetin via antioxidant activity," Anticancer Research, vol. 19, no. 5, pp. 4221-4227, 1999.

[35] T. Q. Pham, F. Cormier, E. Farnworth, H. van Tong, and M.-R. van Calsteren, "Antioxidant properties of crocin from Gardenia jasminoides Ellis and study of the reactions of crocin with linoleic acid and crocin with oxygen," Journal of Agricultural and Food Chemistry, vol. 48, no. 5, pp. 1455-1461, 2000. 


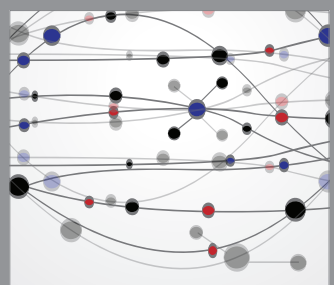

The Scientific World Journal
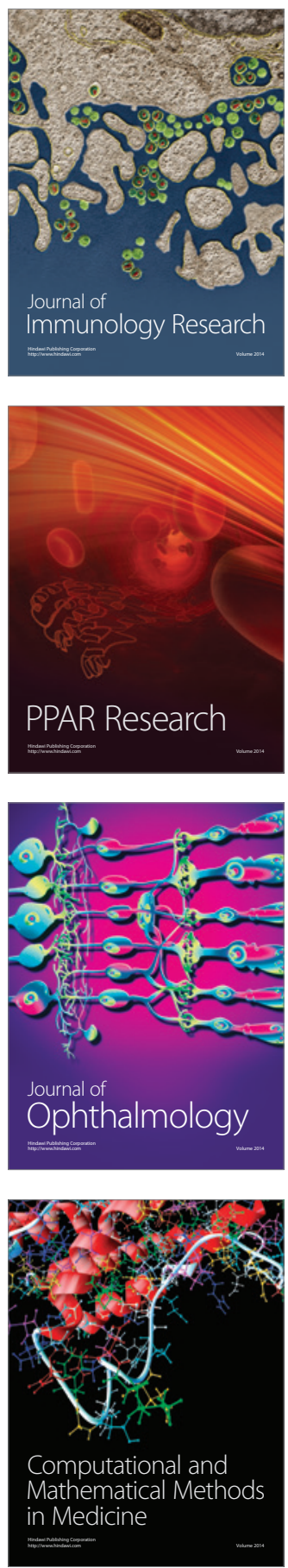

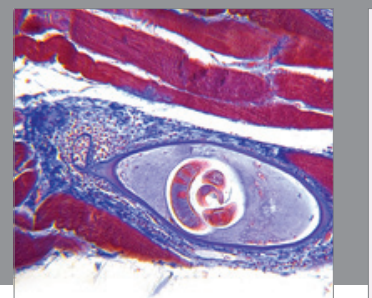

Gastroenterology

Research and Practice
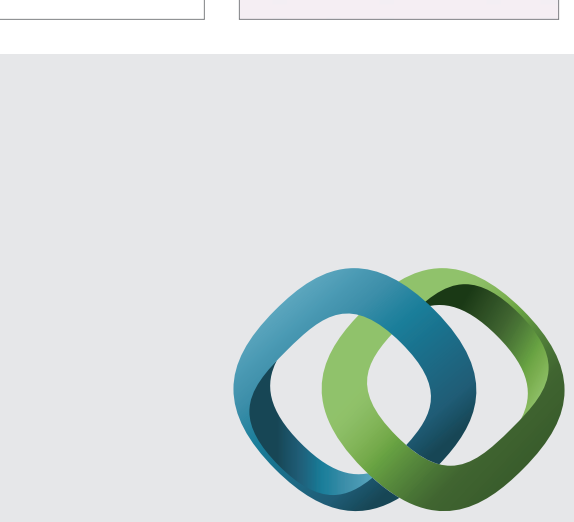

\section{Hindawi}

Submit your manuscripts at

http://www.hindawi.com
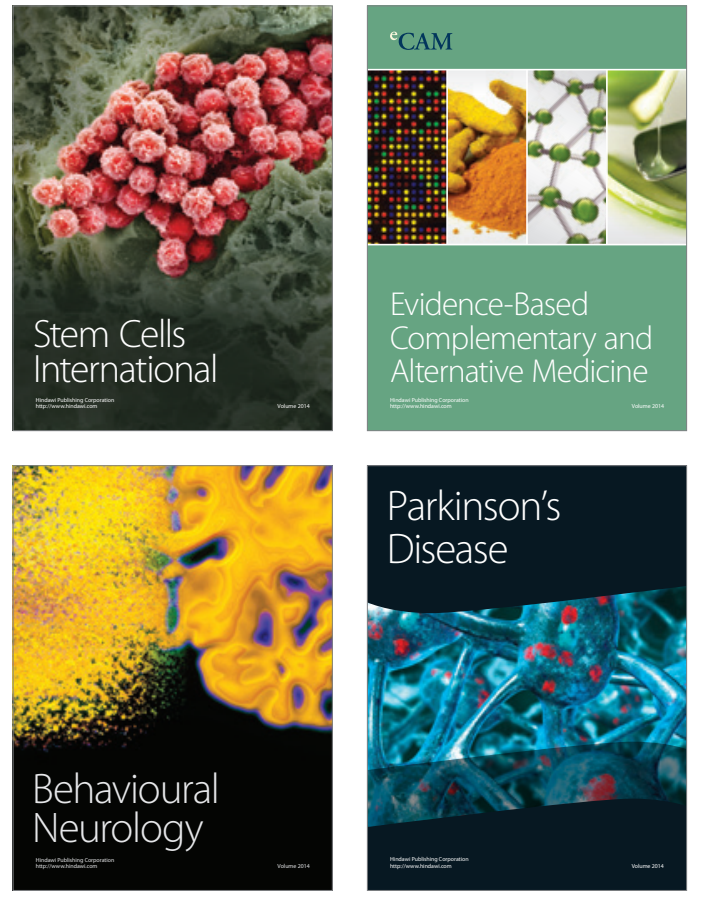
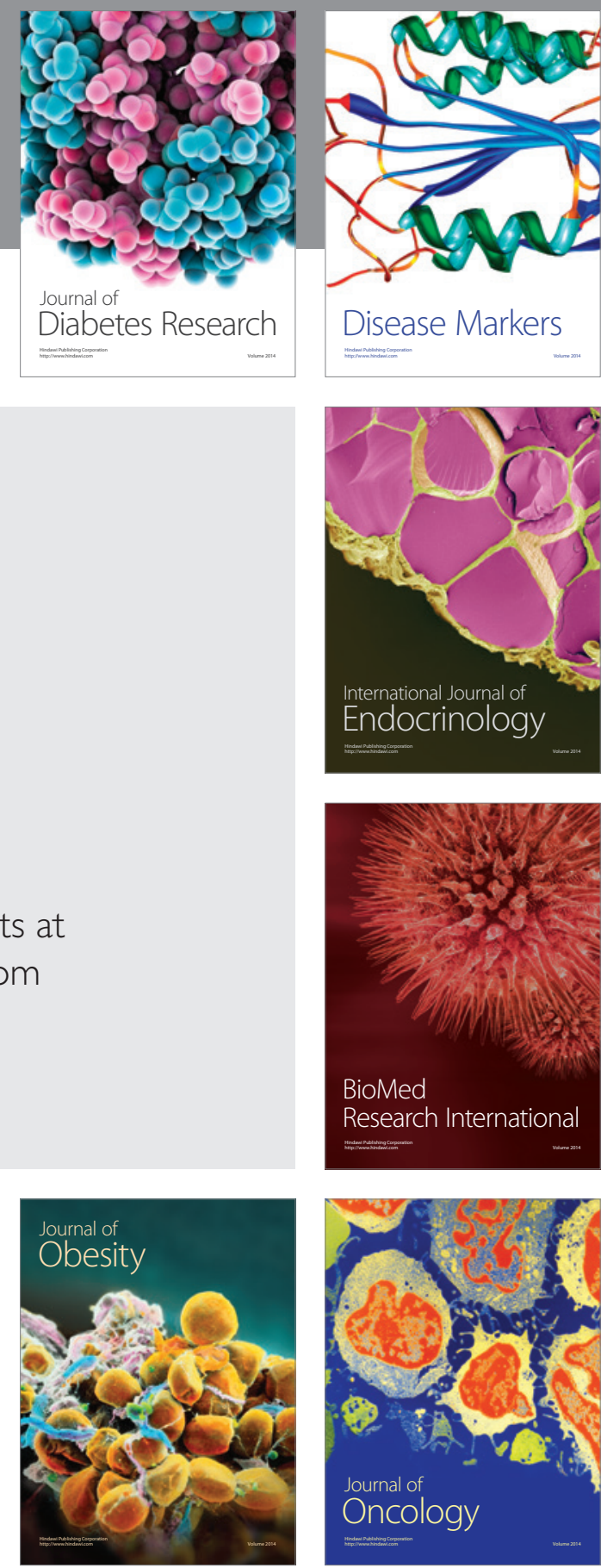

Disease Markers
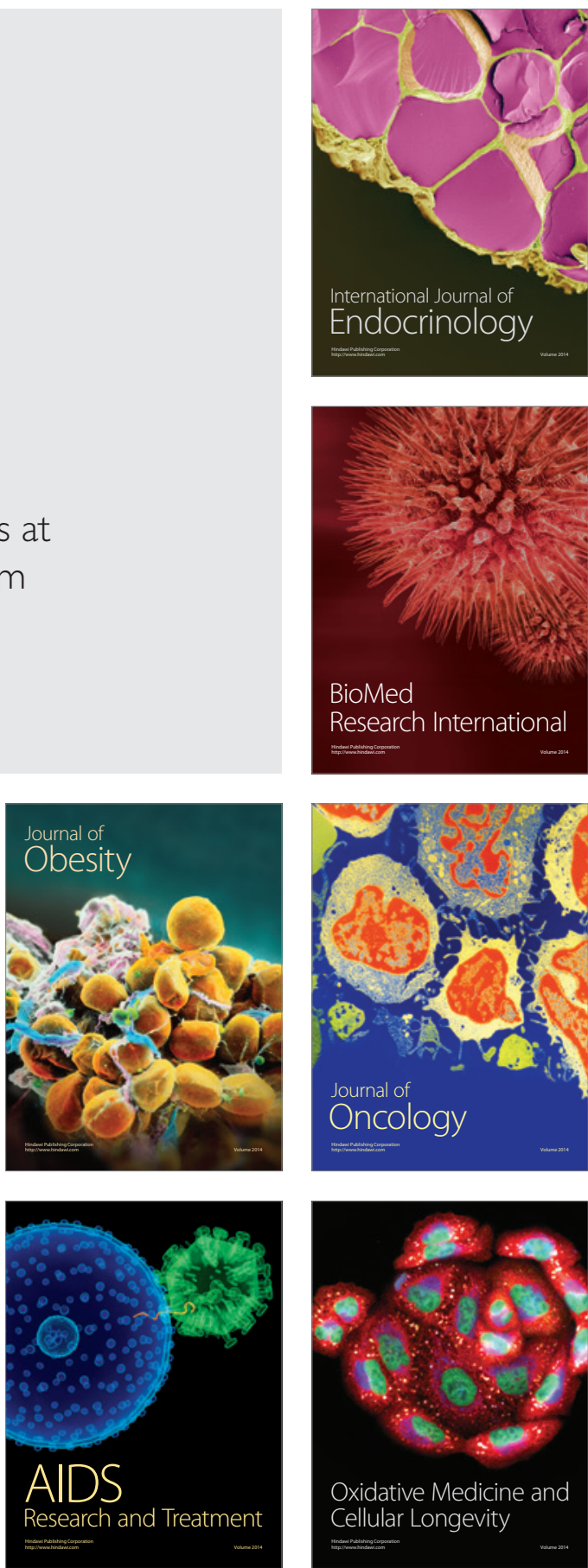